\title{
El barroco: una forma de ser
}

\section{Adolfo Castañón}

Bolivar Echeverría, (comp.) Modernidad, mestizaje cultural, ethos barroco. México, Ediciones El Equilibrista / Coordinación de Humanidades de la UNAM, 1994, 393 pp.

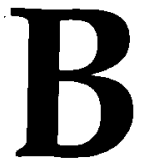

arroco es una palabra cabalística y como de ensalmo y encantamiento, de ésas que los niños y magos ponen en fórmulas secretas. Designa en principio una deformidad en una perla, también un silogismo (baroco) y una deformidad (berrueco). A partir del siglo XVII se asimila al vocabulario de la crítica y de la historia del arte, primero en forma restrictiva y despectiva y luego descriptiva, especializada, pero la realidad estilística a que alude se remonta por lo menos a la época de la primera romana que acusa la influencia recargada y extravagante de los llamados escritores asiánicos, como recuerda Hugo Friedrich en su ensayo sobre Estacio y el manierismo literario. Más acá, en la infancia liberal y cardenista nos enseñaron que barroco era sinónimo de torcido y enrevesado, aun de jesuítico y conservador. El barroco se asocia a las curvas y a las hipérboles y su línea de construcción parabólica es sospechosa ante las líneas ascendentes del progreso. Sinuoso, ahuecado, esférico, reiterativo, reflexivo, de obstinado rigor. Germen de perplejidad porque en él anida o la plenitud o la decadencia, prolífico, exuberante, apela por definición a los sentidos y por definición los niega. Tiene siempre algo de oriental y sería más persa que egipcio, más refinado que bárbaro, inquieto, culterano, conceptuoso, racional y a la vez ingenioso. $\mathrm{El}$ ingenio es de hecho un elemento clave en el campo semántico del barroco y un ingrediente indispensable también de la cultura crítica moderna, según hace ver José Antonio Marina en su brillante Elogio y refutación del ingenio. El barroco - repiten los que dicen saber-es arte de decadencia, de opulencia y soponcio, y figuraría en la tabla periódica del espíritu el espejismo de una penúltima primavera previa a la muerte o el preludio de una primavera morbosa y desenfrenada. El momento en el cual los rigores del funcionalismo ceden espontáneamente a un apetito de las formas. Pero en el árbol de Navidad del Barroco encontramos suspendidas la contrarreforma y los sonetos, la poesía metafísica inglesa (inspirada directa- 
mente en el sermón hispánico y portugués, según hace ver José Ángel Valente), la poesía desengañada y fría de un Quevedo, pero también la letrilla mordaz y salaz de Góngora y sus imitadores como el brasileño Gregorio de Matos, la pintura flamenca y los artistas del claroscuro, la máquina de guerra jesuita y las formas musicales complejas que preludian la edad clásica, las cuerdas y los claustros, el hedonismo y el masoquismo, la monarquía autoritaria y la semilla de los imperios de papel que hoy llamamos burocracia.

Si en Europa el barroco es sintoma estilístico de gerontocracias aletargadas y morganáticas, indicio de príncipe hechizado o de poder absoluto, indicio de corrupción y carcinoma derrochador, en América lo barroco se superpone al aluvión medieval europeo y a la heterogeneidad cultural de los sometidos aborígenes e importados y auspicia una prórroga del Renacimiento allá malogrado. Y mientras los barrocos español, italiano y portugués convocan las más de las veces imágenes delirantes, emblemáticas de la tensión, el éxtasis y el suplicio, en el Orbe indiano - para decirlo con Brading-aquellas mismas imágenes cobran promesa y resplandor hospitalarios y de arte de la Contrarreforma pasa a disimularse como expresara José Lezama Lima en arte de la contraconquista haciendo de América el laboratorio de una modernidad perversa, como sugieren Echeverría, Kurnitzky y Sousa Santos en Mo dernidad, mestizaje cultural, ethos barroco. Por eso a las resonancias declinantes de la convulsión y la esterilidad, de la artificiosa maquinaria verbal achacada por Borges a Gracián habrá que ir contraponiendo otras tributarias también de otras culturas, las del barroco americano, esa subcultura perdurable y triunfante, devoradora, ethos abierto cuyo desarrollo y fisonomía sugieren aquellas suntuosas selvas de mármol teatralmente decoradas a la americana que aún se pueden ver hoy en los templos jesuitas de las ciudades flamencas -Gante, Amberes, Malines- y que son como el símbolo vivo de la influencia que sobre esos amaneramientos originalmente europeos ejerce el paisaje, ese espacio gnóstico americano, para insistir con voces de Lezama. Europeos y no occidentales, América está al occidente de Europa, pues el calambre barroco -ya desde Roma- venía de Oriente.

En Modernidad, mestizaje cultural, ethos barroco -libro que cosecha un simposio, libro saludable que es como un curso intensivo de verano para el aprendiz o una vacación reminiscente y amena, polémica para el especialista, libro ideal para el viajero inmóvil-aprenderemos como en una tanda académica que en la cultura barroca el americano encuentra por primera vez orden civil, figura ritual, letra para su música sinuosa y cifra artística para sus injertos y sus híbridos, encuentra nombre y templo, cocina y verso, música y política. Ya su Majestad el barroco, el primer americano, nos había sido expuesto por José Lezama Lima quien en 1957 prosiguió y bifurcó las líneas genealógicas, las etopeyas culturales que han marcado el pensamiento de 
lengua española de este y aquel lado del mar Atlántico, desde la España invertebrada de Ortega y Gasset (que hoy nos parece algo mimética) hasta el Laberinto de la Soledad de Paz y La radiografía de la pampa de Martínez Estrada (y unos años después que Lezama el portugués Eduardo Lourenço en Laberinto de saudade tocaría cuerdas afines al interrogar el orden barroco como cifra de la historia sin historia del Portugal moderno), el barroco es: piedra miliar en la historia de la cultura americana en la medida en que la Colonia -nuestra infancia y Edad Media- se plantea como edad de formación.

Hace dos años, se reunieron en la UNAM un grupo de dieciocho especialistas de diversos países en diversos campos del conocimiento con el objeto de estudiar y discutir tres temas convergentes en el título Modernidad, mestizaje cultural, ethos barroco, libro compilado por el filósofo ecuatoriano radicado en México, Bolívar Echeverría. Filosofia de la cultura practicada desde varias perspectivas - la historia, la sociología, la crítica literaria, la filosofia, la historia del arte, la historia de las mentalidades, la historia de la música, el examen de la cultura-, y desde varias perspectivas, asedio a la evasiva cuestión, a la amplia pregunta sobre las formas del ser americano. La novedad de este libro escrito a varias voces acordadas y afinadas en torno a un conjunto de motivos culturales estriba menos en el descubrimiento de un continente cultural -el barroco y el ethos- que en la sugerente espiral de un acoso simultáneo auspiciado en buena parte por el invisible trabajo colectivo de un seminario sobre el tema que desde hace años dirige Bolívar Echeverría en la Universidad restituyendo de paso a la vida académica su sentido de convivencia intelectual formalmente orientada hacia la configuración de un saber comunitario o de la comunidad. El libro abre con un excurso filosófico debido al propio Echeverría en el cual éste nos previene que el interés por la categoría acuñada como "barroca" por la historia de la cultura nace menos de una pasión arqueológica que de la certeza de encontrar cifrada en ella, al menos en parte, la crisis de la modernidad que lo es también de la civilización. En efecto, el barroco como talismán hermenéutico había sido trabajado en nuestro Nuevo Mundo ya desde 1957 por Lezama en La expre. sión americana. El ethos barroco - la voz es ya suya- nos anuncia que en la substancia cultural americana hay un sutil movimiento de absorción y contraconquista, un trabajo gnóstico del espacio que reconciliaría naturaleza y cultura en la entidad del paisaje o naturaleza renacida en forma. Desde otra perspectiva, Bolivar Echeverría accede a planteamientos convergentes que serán, junto con los del filósofo alemán invitado Horst Kurnitzky, por así decir, el marco teórico, la maría luisa conceptual del simposio. Nos advierte Echeverría: "Cuatro serían así, en principio, las diferentes posibilidades que se ofrecen de vivir el mundo dentro del capitalismo [...]" un ethos realista -de identificación positiva y militante con los procesos de reproducción 
capitalista; 2) un ethos romántico que naturaliza el orden capitalista transfigurándolo en su contrario; 3) un ethos clásico que vive "la espontaneidad de la realidad capitalista como el resultado de una necesidad trascendente". Y por fin, un ethos barroco:

La cuarta manera de interiorizar al capitalismo en la espontaneidad de la vida cotidiana es la del ethos que quisiéramos llamar barroco. Tan distanciada como la clásica ante la necesidad trascendente del hecho capitalista, no lo acepta sin embargo, ni se suma a él sino que lo mantiene siempre como inaceptable y ajeno. Se trata de una afirmación de la 'forma natural' del mundo de la vida que parte paradójicamente de la experiencia de esa forma como ya vencida y enterrada por la acción devastadora del capital Que pretende restablecer las cualidades de la riqueza concreta re-inventándolas, informal o furtivamente como cualidades de "segundo grado"

El ethos barroco no borra como el realista las contradicciones, tampoco las niega como el romántico, las sabe inevitables como el clásico, pero no las acepta y 'pretende convertir en 'bueno' al 'lado malo', por el que, según Hegel, avanza la Historia". Cada uno de esos ethos ha tenido su época, su mejor y más influyente momento en la vida del capitalismo. La crisis de la modemidad que sería una crisis de civilización autoriza a esbozar afinidades y simetrías entre las paradojas y aporías del modo de ser epilogal de la modernidad y el orden de tensas síntesis y contrastes que dramatiza y pone en escena lo barroco.

Simetrías y afinidades que hacen crisis y resultan tanto más reveladoras en un continente como el americano, marcado por el hierro -espada o cruzde la cruzada ultramarina llamada conquista, modelado por los troqueles de la contrarreforma y aquella singular, agresiva modernidad inventada por Loyola y los jesuitas y que representa -dice Bolívar Echeverria-

[...] el intento de la Iglesia Católica de construir una modemidad propia, religiosa, que girara en torno a la revitalización de la fe - planteado como alternativa a la modernidad individualista abstracta, que giraba en tomo a la vitalidad del capital-, y que debió dejar de existir cuando ese intento se reveló como una utopía irrealizable.

Esas coordenadas - añadidas al hecho incontestable de la heterogeneidad cultural americana derivada de un cosmopolitismo sui generis y de lo que Luis Weckman ha llamado "la herencia medieval de México"- darían al ethos barroco americano una inédita actualidad crítica pues para evocar al escritor 
chicano Richard Rodríguez ¿cómo no va a ser actual la historia de Tijuana a la hora de la tijuanización del mundó?

Modernidad, mestizaje cultural, ethos barroco incluye 18 textos repartidos en cuatro capítulos: los conceptuales (el primero y el cuarto) y dos históricos (el segundo y el tercero). En otra época se hubiese hablado del libro como una aportación de la historia de la cultura al asunto de la identidad cultural desde varias perspectivas. Hoy acaso diríamos que está en juego la lectura crítica de un código (el múltiple barroco) en función de otro en proceso de constitución (el de los llamados estudios culturales). De los tres conceptos del título acaso el mas débilmente trabajado en términos de investigación concreta y no del planteamiento teórico sea el que concieme a la modernidad, pues los ensayos de Echeverría, Rubert de Ventós, Kurnitzky son filosóficos y los de Monsiváis y Rincón parecen más bien ennumerativos por lo cual sólo el de Boaventura de Sousa Santos suscita el interés con una discusión a la vez informada e interpretativa. Precisamente, de Sousa Santos llamará la atención sobre el carácter plural del ethos, los dos ethos barrocos: uno -expuesto paradigmáticamente por la contribución de García de León-

[...] transgresivo, festivo, profano (si no es que sacrílego), anárquico, heterogé-neo, mestizado, onírico, popular, de portugueses africanizados, de prostitutas haciendo de esposas y viceversa (o sea el mundo al revés), globalizado pero con un centro débil. Por el otro lado, tenemos el barroco a la Jorge Alberto Manrique: virreinal, jerárquico, aristocrático, protocolario, cada pieza en su lugar, comunitario pero legitimador del poder que no es comunitario, menos excéntrico que céntrico, desengañado del saber racional pero no desengañado del poder. Uno y otro son retóricos, igual que la posmodernidad lo es.

Sousa de Santos nos advierte con tino en el sentido de que el que ethos barroco es menos una substancia que una tarea, no lugar sino método, no topos sino tropos. Y esa tarea de investigación trabaja una línea -la de la frontera, la de la forma cultural y la frontera como forma de vida, lo cual lo lleva a plantear afinidades sugerentes entre barroco y far west que nos son tanto más sugerentes cuanto más conscientes somos de que el país en que vivimos -México- no tiene una frontera con el país del Norte, sino que es todo él frontera, espacio de traducción e inestable socialización entre el Norte y el Sur, En términos geográficos, el libro que nos ocupa trabaja principalmente tres focos, tres fronteras: la mexicana, la andina y la brasileña. En términos temáticos, trabaja con mayor tenacidad los fenómenos relacionados con la religiosidad (Serur, Alba Pastor, Espinosa Fernández y Vilaltella), 
la literatura (Pereda, Celorio y Schumm) y los diversos procesos y modalida. des del mestizaje (Schumm, Alberro, García de León), la historia del arte y la pintura (del Conde y Vilaltella). El libro contiene un dispositivo autocrítico que encarna Jorge Alberto Manrique "Conversando acerca de unas conversaciones" y donde poniendo los puntos sobre las jotas, es decir lanzando cautelas para prevenir el abuso del concepto barroco. Hay también que llamar la atención sobre el hecho de que la solvencia filosófica y teórica de la convocatoria no se vio respaldada por una respuesta igualmente generosa, sobre todo por parte de los hombres y mujeres de letras (Monsiváis, Celorio, Glantz, Pereda) a la hora de establecer la genealogía e historiografia del concepto barroco en la crítica hispanoamericana. Por esta razón, el estudioso echará de menos un examen de la cadena crítica que va de Eugenio D'Ors, Francisco de la Maza, Henríquez Ureña, Alfonso Reyes y Mariano Picón Salas a José Lezama Lima, Octavio Paz y Severo Sarduy. Para satisfacer este apetito dentro del libro, el lector tendrá que conformarse con la intervención de Gonzalo Celorio sobre "Barroco y crítica en la literatura hispanoamericana" donde salta la liebre polémica con Octavio Paz y se demuestra, en concordancia tácita con Elías Trabulse, que sí tuvimos ilustración a diferencia de lo que sostiene Paz, que el barroco y el eclecticismo jesuítico fueron nuestra ilustración. $O$ bien tendrá que leer entre líneas a Monsiváis quien se pregunta hasta qué punto puede ser difundida y socializable la experiencia y la obra de Carpentier, Lezama y Sarduy. En ambos casos, quedará insatisfecho. Modernidad, mestizaje cultural, ethos barroco es un libro que contribuye a enriquecer como quería Lezama Lima' la tradición de las ausencias posibles en la cultura americana. Como dice la brasileña Janice Teodoro en su libro Améri. ca barroca:

[...] en nuestro continente se da un proceso de opresiva estetización de la vida social y la apariencia triunfa sobre los significados políticos. Aquí -dice- la estetización de las formas muchas veces dejó de lado toda reflexión producida por la sociedad europea en los siglos XVIII, XIX y XX. El barroco sobrevive, renace, disimula como si quisiese salvarse, bloqueando el ingreso de América Latina en la modernidad.

Pero ese bloqueo es ya una de las figuras dé la modernidad o mejor de la posmodemidad. El neobarroco nos recuerda que como quería el rey.filósofo Aurelio, los vicios y enfermedades humanas son efímeros pero cíclicos; cíclicos pero efimeros.

'José Lezama Lima, La expresión americana, Edición de Irtemar Chiampi, México, FCE, 1993. 